\title{
Dapedium sp. from the Toarcian (Lower Jurassic) Úrkút Manganese Ore Formation (Bakony Mts., Hungary) and an overview of diversity of dapediiform fishes
}

\author{
Márton Szabó ${ }^{1,2}$ (D) József Pálfy ${ }^{3,4}$ (iD
}

Received: 18 August 2018 / Revised: 10 November 2018 / Accepted: 28 May 2019/Published online: 9 September 2019

(C) The Author(s) 2019

\begin{abstract}
Dapediidae are a characteristic group of deep-bodied Mesozoic actinopterygian fishes with a moderate diversity at genus- and specieslevel. Here, we add a new occurrence to their patchy fossil record and describe in detail a nearly complete dapediid specimen from the pelagic deposit of the Toarcian Úrkút Manganese Ore Formation in the Transdanubian Range of Hungary. The preserved characters represent nearly all anatomically important body parts and allow assignment to Dapedium and comparison with other dapediid genera. This is the first reported occurrence of the order in Hungary and the Carpathian Basin that extends the known geographical range of the genus to the Mediterranean (western Tethyan) Jurassic. A review of the temporal distribution of published occurrences of dapediids permits speculation that the disappearance of exclusively Late Triassic genera, coincident with the end-Triassic extinction event, was likely related to their specialised feeding strategies and light or incomplete squamation. Multiple environmental crises (warming, acidification and anoxia) severely affected reefal habitats and favoured the survival of the generalist-durophagous Dapedium. The Úrkút specimen adds important data to the Early Jurassic, particularly Toarcian Lagerstätte-dominated fossil record of dapediids. In contrast to the end-Triassic, the Toarcian oceanic anoxic event did not lead to genus extinction among dapediids, possibly prevented by adaptations evolved during the preceding and similarly multi-stressor event. Continuing studies of Mesozoic fish specimens in Hungarian collections may provide new records and insights into other groups as well.
\end{abstract}

Keywords Dapedium · Toarcian · End-Triassic $\cdot$ Extinction · Diversity

\section{Introduction}

Dapedium Leach, 1822 is an extinct genus of lower actinopterygian fish, first discovered at Lyme Regis, England. It is characterised by a deep (hypsisomatic), disc-like body,

Márton Szabó

szabo.marton.pisces@gmail.com

József Pálfy

palfy@elte.hu

1 Department of Paleontology, Eötvös University, Pázmány Péter sétány $1 / C$, Budapest 1117 , Hungary

2 Department of Palaeontology and Geology, Hungarian Natural History Museum, Ludovika tér 2, Budapest 1083, Hungary

3 Department of Geology, Eötvös University, Pázmány Péter sétány $1 / C$, Budapest 1117, Hungary

4 MTA-MTM-ELTE Research Group for Paleontology, Ludovika tér 2, Budapest 1083, Hungary interlocking rhomboidal ganoid scales, relatively small mouth, skull bones ornamented by ganoine-tubercles and ridges, hemshaped dorsal and anal fins, dorsal fins with more than 20 rays, and pronounced dorsal and ventral ridge scales (Thies and Hauff 2011; Smithwick 2015; Thies and Waschkewitz 2015; Gibson 2016). The fossil record of Dapedium ranges from the late Norian (Late Triassic) (Tintori 1983; Lombardo and Tintori 2005) to the earliest Aalenian (Middle Jurassic) (Thies and Hauff 2011; Maxwell and López-Arbarello 2018). All confirmed occurrences have been reported from Europe; the only alleged Dapedium find from India (Jain 1973) has been disputed (Maxwell and LópezArbarello 2018). The majority of the material originates from well-known Lagerstätten and strata with exceptional preservation in England, France, Belgium, Italy and Germany (i.e. sites in the western Tethyan shelf or adjoining epicontinental seas). This list is augmented here with a find from a Toarcian black shale-hosted manganiferous ore deposit in Hungary, representing a relatively deep, pelagic environmental setting.

On the basis of tooth morphology and functional morphology of the jaw, Dapedium was interpreted as a 
generalist well-adapted for generalist durophagy (Thies and Hauff 2011; Smithwick 2015; Stumpf et al. 2017). Facultative durophagy may have helped Dapedium in times of increased competition for food resources (Smithwick 2015). Based on a spectacular find of a Dapedium stuck in a shell of a Lytoceras ammonite, scavenging mode of life was also suggested (Thies and Hauff 2011, fig. 13B). According to Thies and Hauff (2012), Dapedium was also a prey animal for larger predators.

The order Dapediiformes (including only the family Dapediidae) was established by Thies and Waschkewitz (2015), who separated dapediids from semionotiform fishes, to which they were formerly attributed. However, the phylogenetic study was restricted to Dapedium. Within Dapediidae, Thies and Hauff (2011) included seven genera (Hemicalypterus, Tetragonolepis, Paradapedium, Heterostrophus, Dapedium, Dandya and Sargodon). Gibson (2016) referred an additional genus, Aetheolepis, to the family. In 2018, a ninth genus Scopulipiscis was introduced and described by Latimer and Giles (2018).

Since the late 1960s, several fish fossils have been reported from the Úrkút Magnanese Ore Formation in Hungary (see in "Previous work" section). A few of these remains are now housed in museum collections, including one specimen bearing diagnostic characters of Dapediidae. The aim of the present study is to provide a detailed anatomical and taxonomical description of this specimen. A summary of the available information allows us to consider the history of diversification of the group, with an emphasis on the possible reasons for selective extinction and survival of dapediiforms at the end-Triassic and Toarcian events.

\section{Previous work}

Mesozoic fish remains from Hungary have been the subject of only a few studies. Toarcian fishes, representing several species, are figured from the black shale facies exposed in the Réka Valley (Mecsek Mountains, southern Hungary) (Főzy and Szente 2014), but have not yet been studied in detail. Dulai et al. (1992) identified only a single species, Leptolepis normandica. With the exception of the Réka Valley material, all other reports are based on isolated remains.

Although fossil fishes of the Úrkút Manganese Ore Formation have been known for more than 50 years, published information is restricted to only a few brief reports. A large specimen was found and figured by Cseh-Németh (1966) as "ganoid fish remain" (note that this specimen is the subject of the present study). Polgári et al. (2000) and Pászti (2004) also figured this specimen as a pycnodontid fish fossil. Pászti (2004) gave the first detailed account on the fish remains of the Úrkút Manganese Ore Formation, describing them as pycnodontiform and amiiform fishes. However, from the three specimens figured by Pászti (2004), only Cseh-Németh's (1966) specimen was found still available in the vertebrate fossil collection of the Mining and
Geological Survey of Hungary (MGSH) in the same condition as originally illustrated. Főzy and Szente (2014, p. 170) figured an additional specimen, which is also housed in the vertebrate fossil collection of the MGSH. Mineralogical and geochemical studies of the phosphoritic nodules that yielded the fish remains from Úrkút were carried out by Polgári et al. (2004).

The Úrkút Manganese Ore Formation that yielded the dapediid specimen described here is a hitherto less known source of exceptional preservation related to bottom water anoxia. The relation of the Úrkút manganese ore deposit to the Toarcian Oceanic Anoxic Event (T-OAE or Jenkyns event, Müller et al. 2017) is well-established (see overviews by Haas 2012 and Polgári et al. 2016a, b). The biological productivity was high in the surface waters, but bottom waters were oxygen-deficient (Polgári et al. 1991).

\section{Geological setting}

The village of Úrkút is located in Veszprém County, in the southern Bakony Mountains, western Hungary (Fig. 1a). Manganese ore mining in the Bakony Mountains started here in the Úrkút Basin in 1917 and was terminated in 2016. The black shalehosted Mn-oxide and carbonate ore body of Úrkút is among the ten largest deposits in the world (Polgári et al. 2013).

The Úrkút Manganese Ore Formation occurs in a large area in the Úrkút Basin. Its thickness reaches $30 \mathrm{~m}$ in the western part of the basin, and exceeds $100 \mathrm{~m}$ in the north-western part of the basin, it includes three ore beds (Polgári et al. 1991; Bíró 2014). The Úrkút ore deposits occur in a NE-SW trending, 12-kmlong and 4- to 6-km-wide zone. The manganiferous ore conformably overlies the Pliensbachian cherty limestone of the Isztimér Formation (Polgári et al. 2012, 2013) (Fig. 1b). The sequence starts with $\sim 0.5 \mathrm{~m}$ of Mn-oxide ore, overlain by $1.0 \mathrm{~m}$ of radiolarian clay marlstone. The main manganese ore body has a maximum thickness of $15 \mathrm{~m}$ and is made up of variously coloured and finely laminated $\mathrm{Mn}$ ore. This unit is followed by $\sim 10 \mathrm{~m}$ of radolarian clay marlstone and $\sim 2.5 \mathrm{~m}$ of manganiferous clay marlstone. The uppermost part of the sequence consists of $2.5 \mathrm{~m}$ of radiolarian clay marlstone, and $2.5 \mathrm{~m}$ of manganiferous clay marlstone. A discontinuous chert layer (Cservár Flintstone Member) represents the closes part of the formation (Bíró 2014). For further details on the geology and stratigraphy of the Úrkút Mn ore deposit, see Szabó and Grasselly (1980), Szabó et al. (1981), Grasselly and Pantó (1988), Polgári et al. (1991, 2012, 2013, 2016a, b), Pantó et al. (1996), Haas (2012) and Bíró (2014).

\section{Material and methods}

Of the four Toarcian fossil fish specimens known from Úrkút, the present study is focused on specimen V.10279 (Fig. 2), 


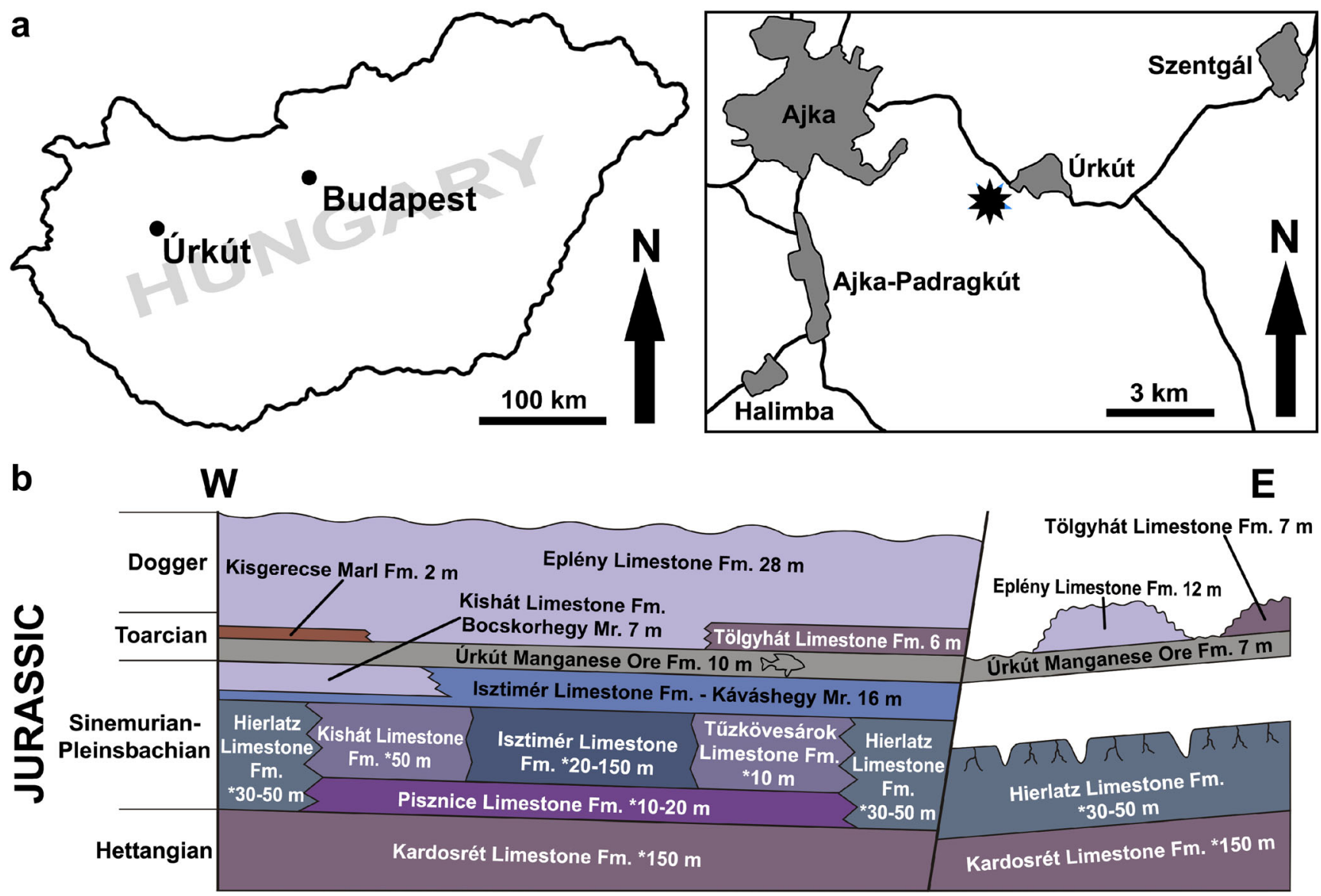

Fig. 1 a Location map of Úrkút. Black star symbol signs the locality. b Schematic geological structure of the Jurassic sediments of the Úrkút Basin (modified after Bíró 2014)

housed in the vertebrate paleontological collection of the Mining and Geological Survey of Hungary (MGSH). The exact stratigraphical level of the specimen is not known, and it was collected from Shaft III (Polgári et al. 2000).

Specimen V.10279 is a moderately well-preserved individual, with a standard length of $233 \mathrm{~mm}$ (measured from the tip of the snout to the end of the caudal musculature). The specimen is laterally compressed and is embedded in a phosphoritic nodule (available as part and counterpart of a splitted nodule), in which it lies in left lateral aspect. Cracks run through the trunk and the skull, which most probably resulted from the breaking of the nodule. Some bones can be observed on both halves, either as fragments or impressions. In some cases, this makes it hard to distinguish some bones from one another, or precisely reconstruct their outline. About half of the skull bones can be examined separately; the others are too poorly preserved or fragmentary for detailed description. The dermal cranial ossifications show more or less natural arrangement. Although Dapedium typically has dermal skull bones ornamented by ganoine, this ornamentation is not preserved on the skull, because of the specimen's general condition and the way the nodule was split. Also for preservational reasons, fine details of several important skull bones are lost, and some parts (e.g. the nasal region) appear to be deformed. Throughout this work, the part and counterpart, and the elements preserved on them are consistently labelled as A and B, respectively.

Due to oxidization of pyrite, specimen V.10279 started to disintegrate. Cyanoacrylate glue was used to reattach the related parts. To avoid further oxidization, V.10279 was also treated with polyvinyl-butyral (PVB). For measuring the scale dimensions, ImageJ software (version 1.48) was used. With slight modifications, the terminology of Thies and Hauff (2011) and Thies and Waschkewitz (2015) was followed in the anatomical description.

For assessment of the history of diversity of dapediiform fishes, a comprehensive dataset was compiled from literature sources. It was checked against occurrence data deposited in the Paleobiology Database.

\section{Systematic palaeontology}

Class: Actinopterygii Cope, 1887

Super Division: Holostei Müller, 1844 (sensu Grande, 2010)

Division: Halecomorphi Cope, 1872

Order: Dapediiformes Thies and Waschkewitz, 2015

Family: Dapediidae Lehman, 1966 


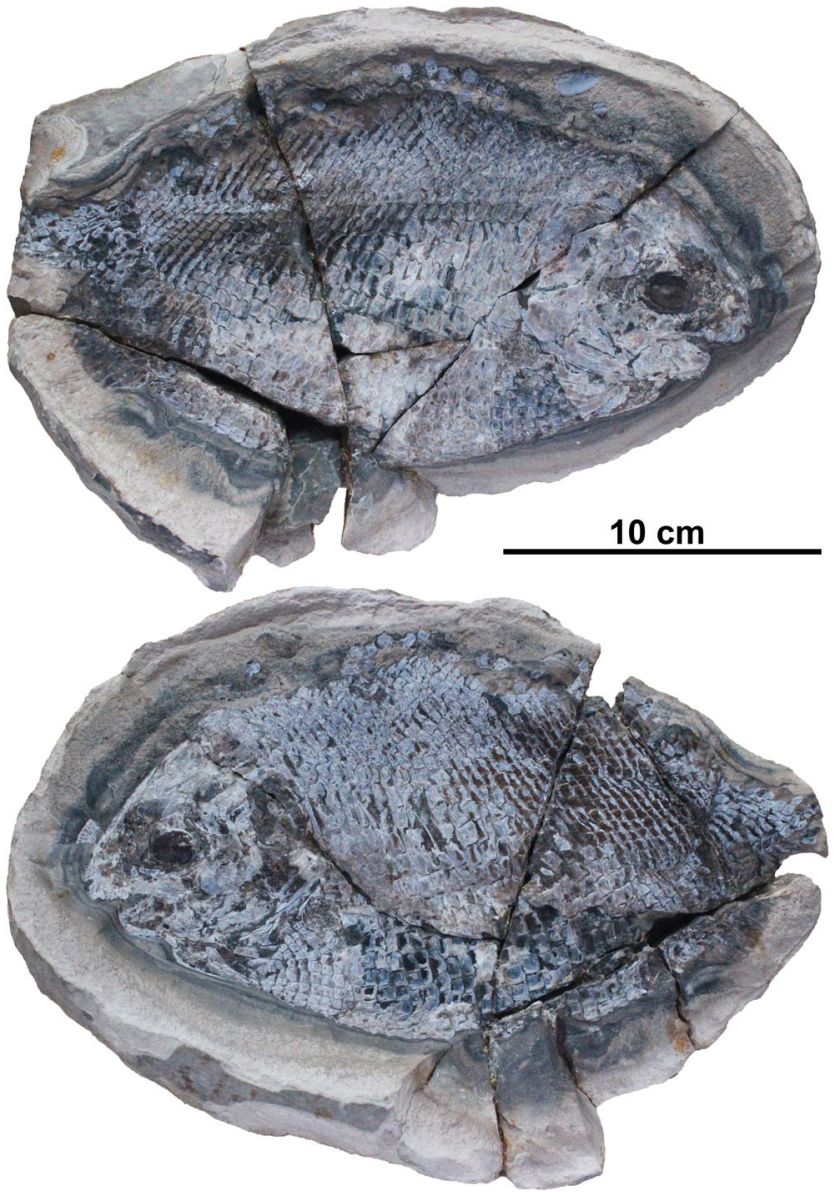

Fig. 2 Dapedium sp. (V.10279; upper: V.10279-B-lower: V.10279-A) from the Toarcian Úrkút Manganese Ore Formation (Úrkút, Hungary)

Genus: Dapedium Leach, 1822

Dapedium sp.

Figs. 2, 3, 4 and 5

Referred material: One individual (V.10279) preserved in a phosphoritic nodule, in lateral aspect.

\section{Endochondral neurocranium}

The endochondral neurocranium is poorly preserved, and almost totally covered by dermal cranial ossifications. Neurocranial parts are visible in the orbit, and less clearly in the postorbital region. The orbital portion of the braincase is represented by a greyish bone element, which is tentatively referred as the basisphenoid, which dorsally continues into the interorbital septum (Fig. 3, ios). A large and circular interorbital fenestra is seen posteriorly to the interorbital septum (Fig. 3, iof).

Dermal neurocranium

Rostral, nasal and antorbital: This part of the cranium is deformed, the outline of the rostral, nasal, and antorbital
(Fig. 3, RoNaAnt) cannot be properly observed. The exact position and shape of the anterior nasal opening (Fig. 3, ano) is uncertain. Therefore, it cannot be established whether the antorbital, the rostral and the nasal make up the outline of the anterior nasal opening together, or only the rostral and the nasal. It is also uncertain, whether the rostral is paired or unpaired. A bony, spike-like structure, directed anteroventrally, is positioned on the anterior outline of the presumed rostral (Fig. 3, asls). It is unclear, whether it is a separate anatomical element (i.e. the extremity of the ethmoid complex), or only a portion of the counterpart of a possibly paired rostral, and it is a result of the deformity of the rostral region of the cranium.

Dermopterotic, parietal and frontal: This bone-complex (Fig. 3, DerPaFr) forms the major part of the skull roof; however, the sutures cannot be separated properly due to the poor preservation. A crack runs through the posterior part of the DerPaFr (see Fig. 3).

Extrascapulars: These plate-like dermal ossifications (Fig. 3, Esc) are arranged in a series behind the dermopteroticparietal-frontal region. They are rectangular in shape, as typical for species of Dapedium. The series includes at least five plates on the observable side of the skull.

Circumorbitals: The series of circumorbital bones comprises bones surrounding the orbit dorsally, ventrally and caudally, including the supraorbital, dermosphenotic, infraorbitals and suborbitals:

Supraorbital: Not preserved in the studied specimen.

Dermosphenotic: This bony plate is placed dorsally to the orbit (Fig. 3, Dsph). It is rectangular in shape, and it fits laterally to the DerPaFr-complex. Due to its preservation, sensory canals of dermosphenotic cannot be investigated in V.10279.

Infraorbitals: The infraorbital series (Fig. 3, Io) is incompletely preserved. It includes rectangular bone-plates, placed ventrally around the orbit. However, this portion of the skull is also heavily damaged, and only some infraorbitals are preserved in their original position and with original outline.

Suborbital: Similarly to other circumorbital bones, these elements are also rectangular in shape (Fig. 3, Sor). Outlines of some damaged suborbital plates are observable. The boundary of the infraorbitals and suborbitals is not clear due to the preservation level of this skull region.

Parasphenoid and vomer: No remains of these bones can be seen in V.10279.

Visceral skeleton

Mandibular arch: endochondral elements

Palatoquadrate and articular: No remains of these bones can be seen in V.10279. 


\section{a}
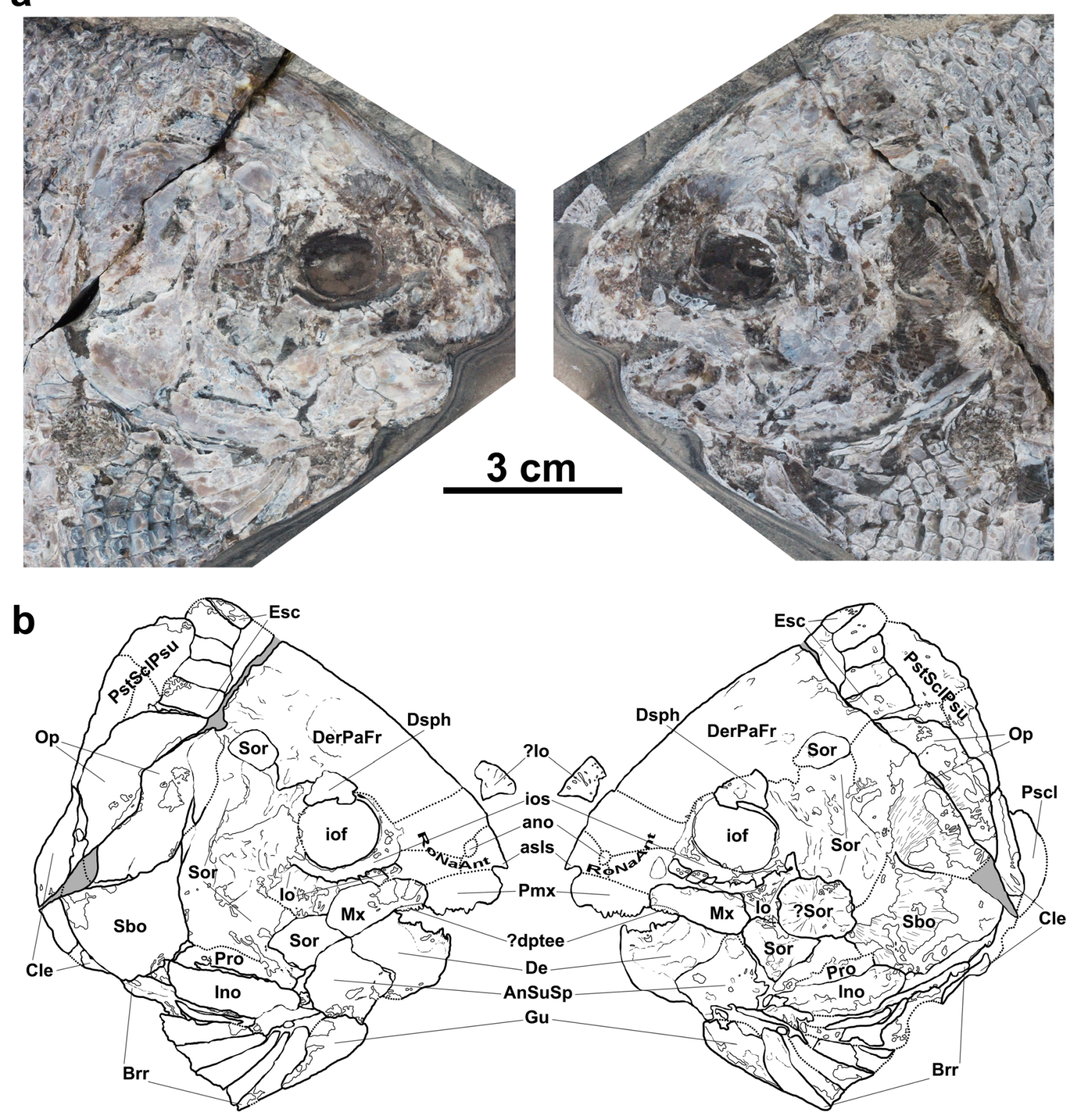

Fig. 3 a Cranium of V.10279 (on the left: V.10279-B - on the right: V.10279-A). b Line drawings of the same views. ano anterior nasal opening; AnSuSp co-ossified angular-supraangular-splenial; asls anterior spike-like structure on the suggested rostral; $\mathrm{Brr}$ branchiostegal rays; $\mathrm{Cle}$ cleithrum; $\mathrm{De}$ dentale; $\mathrm{DerPaFr}$ co-ossified dermopterotic-parietalfrontal; ?dptee dermopalatine teeth; Dsph dermosphenotic; Esc

\section{Mandibular arch: dermal elements}

Premaxilla: This paired element forms the tip of the snout (Figs. 3 and 4, Pmx). The premaxillae are bordered dorsally by the rostral (or rostrals), and laterocaudally by the maxillae. In V.10279, the premaxillae are damaged. Premaxillary teeth of V.10279 are of simple morphology, and they are unicuspid, conical with blunted tip, decreasing in height posteriorly (see Fig. 4). Maxilla: The maxilla is wedge-shaped, runs anteroposteriorly and broadens posteriorly (Figs. 3 and 4, Mx). In V.10279, the extrascapular series; $G u$ gular plate; Ino interoperculum; Io infraorbital series; iof interorbital fenestra; ios interorbital septum; $M x$ maxilla; $O p$ operculum; Pro preoperculum; PscStlPsu region of posttemportalsupracleithrum-presupracleithrum; $P m x$ premaxilla; $P s c l$ postcleithrum; RoNaAnt region of rostral-nasal-antorbital; Sbo suboperculum; Sor suborbital series. Dotted lines refer to uncertain bone outlines

caudal margin of the maxilla is hardly separable from the anterior margin of the anteriomost infraorbital elements.

Dermopalatine: In V.10279, only a few poorly preserved teeth are referred to the possible dermopalatine (Figs. 3 and 4, ?dptee). These teeth are positioned dorsally to the rostral end of the maxilla, and since maxilla of Dapedium usually does not bear teeth, here, these teeth are regarded to belong to the dermopalatine (however, the boundary between the possible dermopalatine and the maxilla is obscure). Similarly positioned dermopalatine teeth are figured by Thies and Hauff (2011), figs. 1 and 3). 

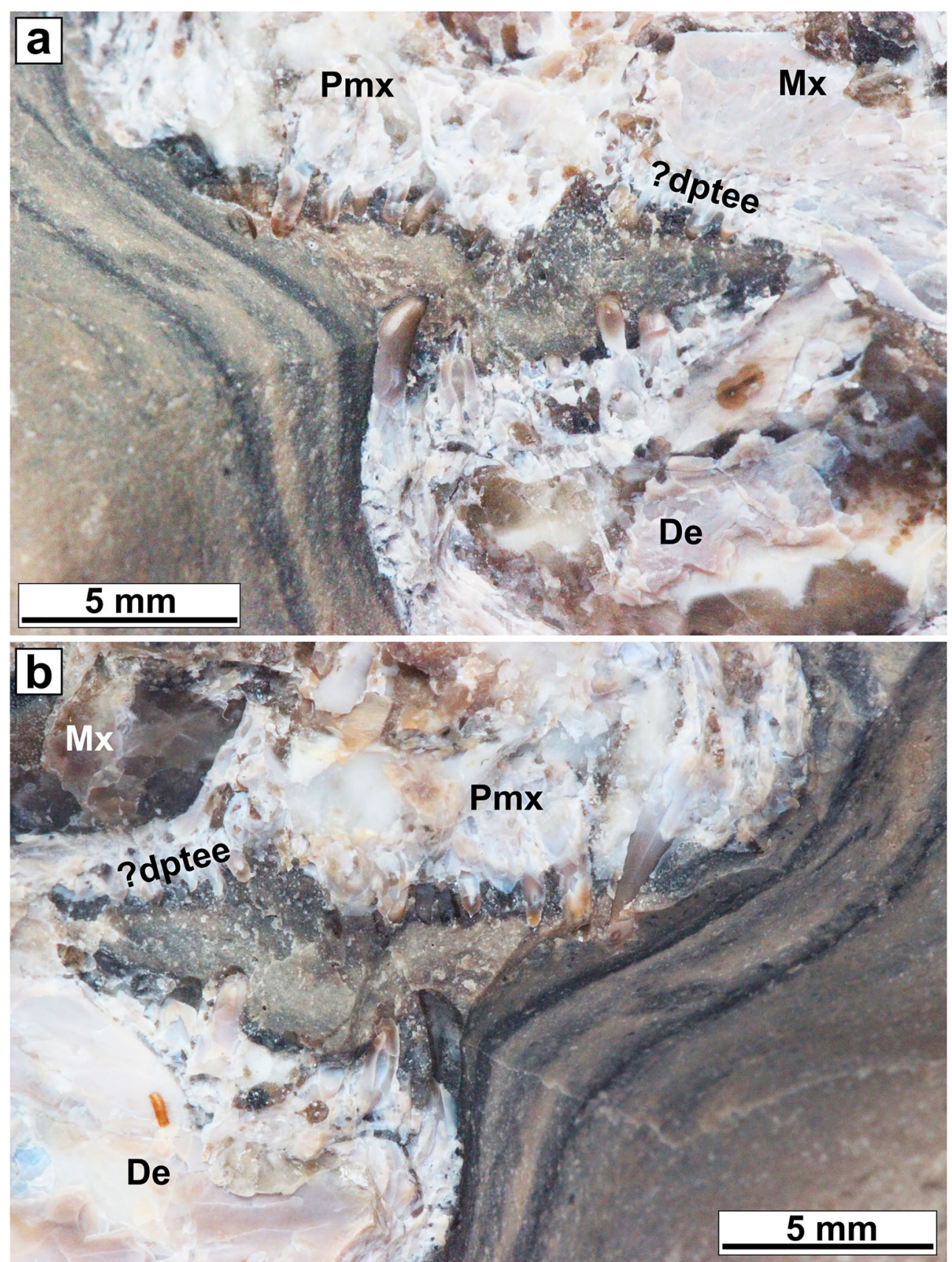

Fig. 4 Upper and lower jaw of V.10279 (a V.10279-A—b V.10279-B). Note the conical, unicuspid teeth. De dentale; ?dptee dermopalatine teeth; Mx maxilla; Pmx premaxilla

Dentary: The dentary of V.10279 is independent (Figs. 3 and $4, \mathrm{De})$, and separated from the co-ossified angular, supraangular and splenial (Fig. 3, AnSuSp). The independent dentary in the early Toarcian Dapedium species has been reported by several authors (e.g. Thies and Herzog 1999; Thies and Hauff 2008, 2011). This variation of the dermal bones of Dapedium was considered as intraspecific variability by Thies and Herzog (1999). The anteriomost end of the lower jaw cannot be observed.
Dentary of V.10279 bears simple, unicuspid, conical teeth with blunted tip, decreasing in height posteriorly (see Fig. 4). An anterior tooth bends distally.

Coronoids: No coronoids can be seen in V.10279.

\section{Hyoid arch: endochondral elements}

Only a few barely visible bone-fragments can be referred with certainty as ventrorostral parts of the ceratohyal. 


\section{Hyoid arch: dermal elements}

Operculum: The relatively well-preserved operculum (Fig. 3, Op) posteriorly rests against the cleithrum, and ventrally against the supracleithrum. According to measurements taken on both part and counterpart, based on the preserved outline of the operculum, its rostral and ventral borders are forming an obtuse angle of $123^{\circ}$ and $127^{\circ}$. This bone element is $1.4 \times$ higher than wide.

Suboperculum: This bone (Fig. 3, Sbo) has slightly convex caudoventral and rostroventral margins; it borders the operculum with a nearly straight dorsal margin, which ends in an acute angle dorsorostrally.

Interoperculum: The interoperculum (Fig. 3, Ino) is simple, elongated tongue-shaped in lateral view. Anteriorly, it ends near to the caudoventral end of the lower jaw. The dorsolateral surface articulates with the medial surface of the preoperculum. The interoperculum is bordered ventrally by the first branchiostegal ray.

Branchiostegal rays: At least six branchiostegal rays (Fig. 3, Brr) are present as anteroposteriorly elongated bone elements. They converge to the suggested position of ceratohyal, behind the gap between the gular and the caudoventral border of the lower jaw, under the anterior end of the interoperculum, forming a fan-like structure. This is a typical structure of branchiostegal rays for Dapedium (see figures of Thies and Hauff 2011 and Thies and Waschkewitz 2015).

Gular plate: The median gular plate (Fig. 3, Gu) is positioned ventrally to the ventrocaudal end of the lower jaw, and anteriorly to the last branchiostegal ray. Its exact shape cannot be determined.

Preoperculum: The preoperculum (Fig. 3, Pro) is positioned dorsally to the interoperculum. It is horizontally elongated and slender, albeit hardly visible on V.10279. This element is a bony tube for the vertical branch of the preopercular canal (Thies and Waschkewitz 2015).

Branchial apparatus: The branchial apparatus is not visible on V.10279.

\section{Postcranial skeleton}

Axial skeleton: The axial skeleton is covered by scales; no internal remains of it are observable.

Endochondral shoulder girdle: Endochondral elements of the shoulder girdle of V.10279 cannot be observed.

\section{Dermal shoulder girdle}

Posttemportal, supracleithrum and presupracleithrum: These bones are damaged and/or partially covered by other bone elements; therefore, they are not distinguishable (Fig. 3, PstSclPsu). The presence of presupracleithrum has been reported in D. pholidotum, D. politum and D. punctatum (Wenz 1967; Thies and Waschkewitz 2015). In Dapedium, the platelike posttemporal connects the dermal shoulder girdle with the skull roof. Caudally, it is bordered by the squamation, while rostrally by the extrascapular series.
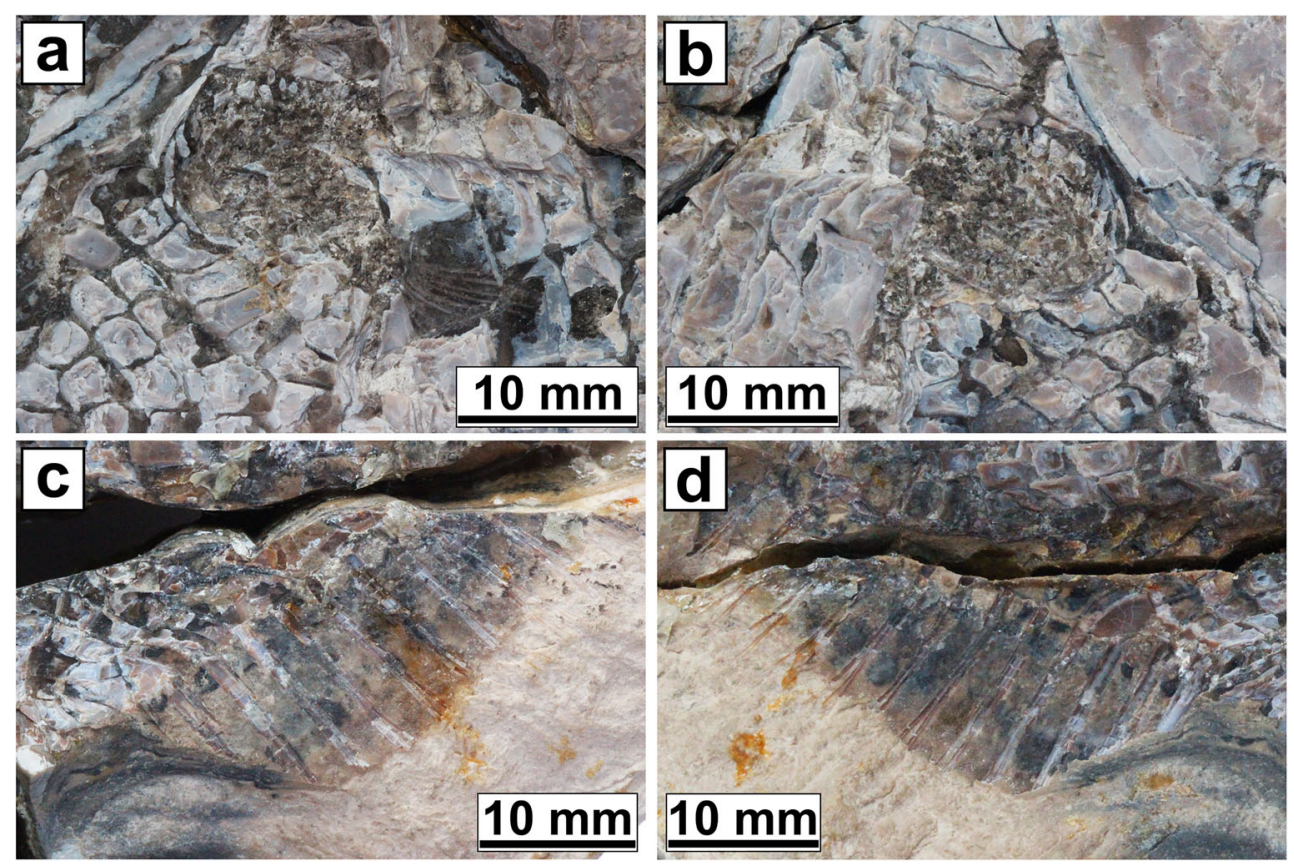

Fig. 5 a, b Pectoral fin of specimen V.10279 (a V.10279-A — b V.10279-B). c, d Anal fin of specimen V.10279 (c V.10279-A - d V.10279-B) 
Cleithrum: The cleithrum of V.10279 (Fig. 3, Cle) is poorly preserved and heavily damaged. The preserved portion indicates that it does not differ from that of other Dapedium species. The cleithrum is a narrow, rostrocaudally bent bone element. The exposed dorsal end terminates at around the midpoint of the caudal margin of the operculum. The ventral end is fragmentary, but it would have most likely ended under the branchiostegal rays.

Postcleithrum: Remains of postcleithra in V.10279 are obscure, since this region is heavily damaged. Some faint remains of the margin of a possible postcleithrum (Fig. 3, Pscl) are present on the counterparts of
V.10279. The number of postcleithra varies in species of Dapedium (Thies 1988; Thies and Hauff 2008; Thies and Hauff 2011; Thies and Waschkewitz 2015).

\section{Paired fins}

Pectoral fins: On V.10279, only the base of left pectoral fin is preserved (Fig. 5a, b). Further anatomical details of the pectoral fin remain obscure. The pectoral fin is positioned high on the flank, and behind the fragmentary ventral section of the cleithrum.

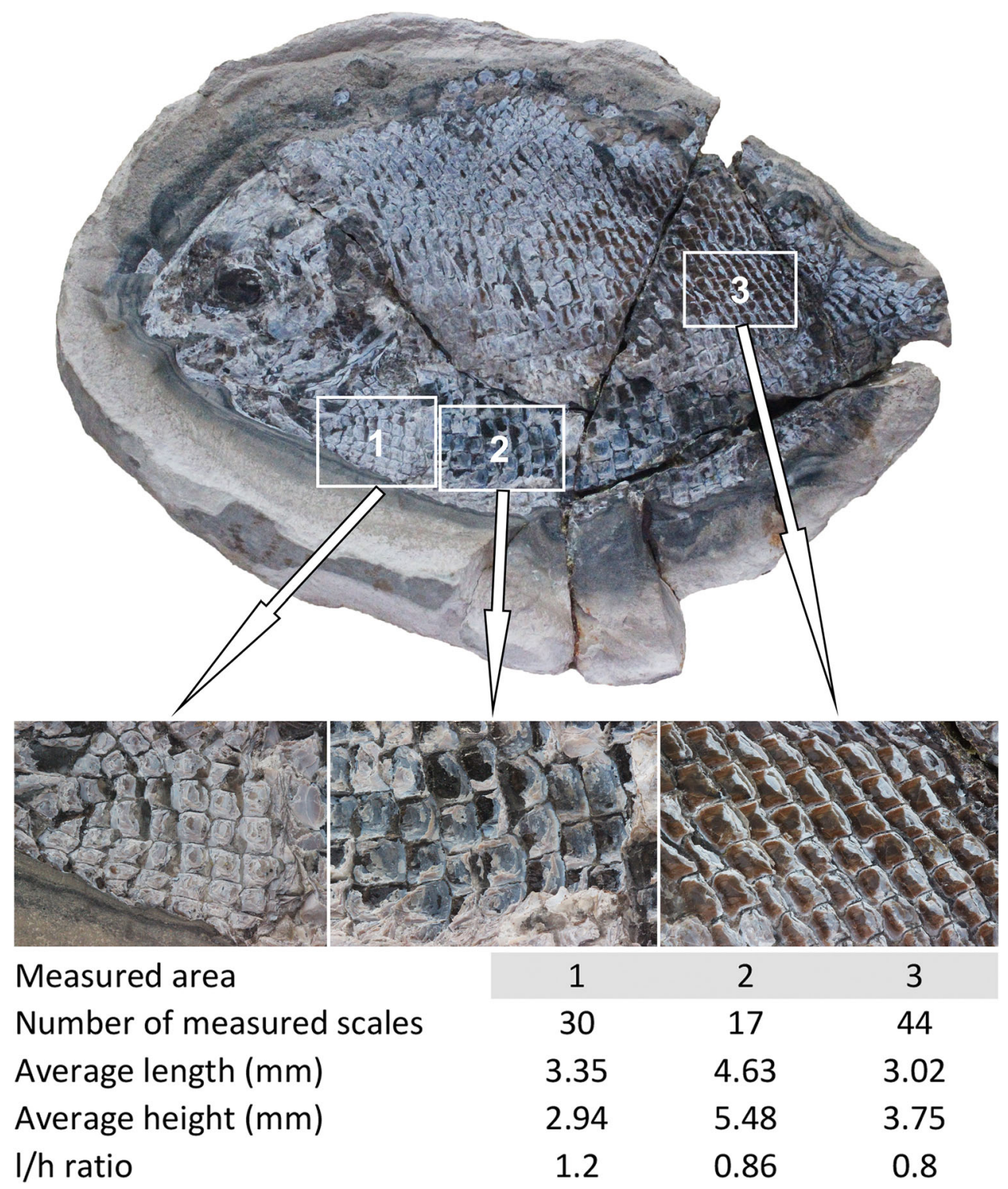

Fig. 6 Measurements of the squamation of specimen V.10279-A. Numbers show the measured areas 
Pelvic girdle and fins: Part of the ventral part of the body of V.10279 is missing, probably resulting in the loss of the pelvic girdle and the pelvic fins.

\section{Unpaired fins}

Dorsal fin: No remains of the dorsal fin are seen in V.10279, as it may be covered by the matrix, but further preparation of the specimen is too risky due to its condition.

Anal fin: The preserved parts of the anal fin suggest a seamor hem-like anal fin, comprising at least 14 lepidotrichia (among them two are almost fully covered by the matrix), nearly equal in size (Fig. 5c, d).

Caudal fin: The caudal fin of V.10279 is completely missing. Scales and squamation: The trunk is fully covered by shiny, rhomboidal ganoid scales. The preserved scales are arranged in 38-39 vertical and 29-30 horizontal rows (these numbers are approximate only, because the crack surface between the left and right counterparts is irregular; hence, in some cases, it cannot be established, which side a scale row or section of a scale row belongs to). There are incomplete vertical rows above and below the shoulder girdle. The vertical rows are slightly curved. The scales have simple, unserrated outline. The better preserved scales have a smooth surface, and the ganoine is developed as a single, continuous layer. The size and proportions of the scales vary according to their position on the body (Fig. 6; measurements were taken on body parts with less fragmentary squamation to indicate the relative size and morphology of scales in different regions). Dorsal and ventral ridge scales are present but poorly preserved.

\section{Taxonomic comparisons and remarks}

The preserved anatomical features of the Úrkút dapediid allow its generic assignment and distinction from the eight other dapediid genera (Gibson 2016; Latimer and Giles 2018). Based on the fossil record, among these Hemicalypterus, Sargodon, Dandya and Scopulipiscis seem to went extinct at the end of Triassic, whereas the Úrkút specimen is Toarcian in age. Apart from the difference in age, Hemicalypterus has a cycloidal body, with scaleless posterior body half (Gibson 2016), whereas squamation of Sargodon (whose body shape also differs from that of V.10279) becomes extremely thin posteriorly (Tintori 1983). In contrast to these two genera, the entire body of the Úrkút dapediid is covered by shiny ganoid scales, only slightly variable in proportion. Moreover, Hemicalypterus has multicuspid premaxillary and dentary teeth (Gibson 2015), unlike V.10279 which shows simple, unicuspid teeth. According to Tintori (1983), Dandya is rather similar to Dapedium in the arrangement of the skull bones, but it differs in having rounded to slightly convex posterior scale margins, and lighter scale cover, in contrast to the thick, rhomboidal ganoid scales of V.10279. The operculum of the Triassic species $D$. ovalis is at least twice as high as long (Tintori 1983), whereas V.10279 has an operculum only $1.4 \times$ higher than wide. In addition, D. ovalis has shorter and fewer branchiostegal rays, compared to the Úrkút dapediid (Gorjanović-Kramberger 1905; Tintori 1983). The head of Dandya is proportionally much larger than that of all other dapediid genera (see Gorjanović-Kramberger 1905, fig. 25; Tintori 1983, fig. 3; Schultz 2013, pl. 22, fig. 1). Scopulipiscis is an extremely large-sized dapediid from the Rhaetian, with a neurocranium that reaches $17 \mathrm{~cm}$ in length (Latimer and Giles 2018). This species is substantially different from the Úrkút specimens, which has a full cephalocaudal length of $233 \mathrm{~mm}$, and is Toarcian in age. For these reasons, V.10279 does not belong to any of these four genera.

The genus Tetragonolepis has a ventrally much more protuberant body (Thies 1991) compared to the Úrkút dapediid. The trunk scales have clearly different proportions depending on their dorsoventral and caudorostral position (Thies 1991, text-fig. 37), whereas V.10279 has only slightly variable squamation. The branchiostegal rays of Tetragonolepis semicintca posteriorly decrease in size (Thies 1991), whereas V.10279 bears branchiostegal rays that are nearly equal in size and shape. According to Jain (1973), Tetragonolepis oldhami displays three branchiostegal rays that become progressively larger from the anterior, unlike those of the Úrkút specimen. Finally, Tetragonolepis spp. are generally much smaller (with maximal body length of $18 \mathrm{~cm}$; Thies 1991) than the Úrkút specimen.

Paradapedium was first described in detail by Jain (1973), from the Lower Jurassic of India (through its type species $P$. egertoni). Branchiostegal rays are diagnostically inconspicuous in this genus, which is different from V.10279. In addition, the Úrkút dapediid has much less protuberant ventral abdominal region, than Paradapedium (cf. Jain 1973, text-figs. 3, 5, 6 and pl. 14).

Eastman (1914) states that Heterostrophus (originally described as Homoeolepis in his work) is similar to Tetragonolepis, but it can be distinguished by its less protuberant ventral body region, lower positioned pectoral fins, and having more scales in the vertical scale series below the vertebral axis. The specimen figured by Eastman (1914) as Homoeolepis suborbiculata was re-described by Lambers (1999) as Heterostrophus latus. Woodward (1929) states that ganoine is either thin or almost absent on the external surface of the scales of another species of this genus, Heterostrophus phillipsi, whereas scales of Dapedium are covered by a thick, well-developed layer of ganoine. According to this author, the maxilla of both $H$. latus and $H$. phillipsi bears teeth. Although this feature is not clearly seen in V.10279, here, we suggest 

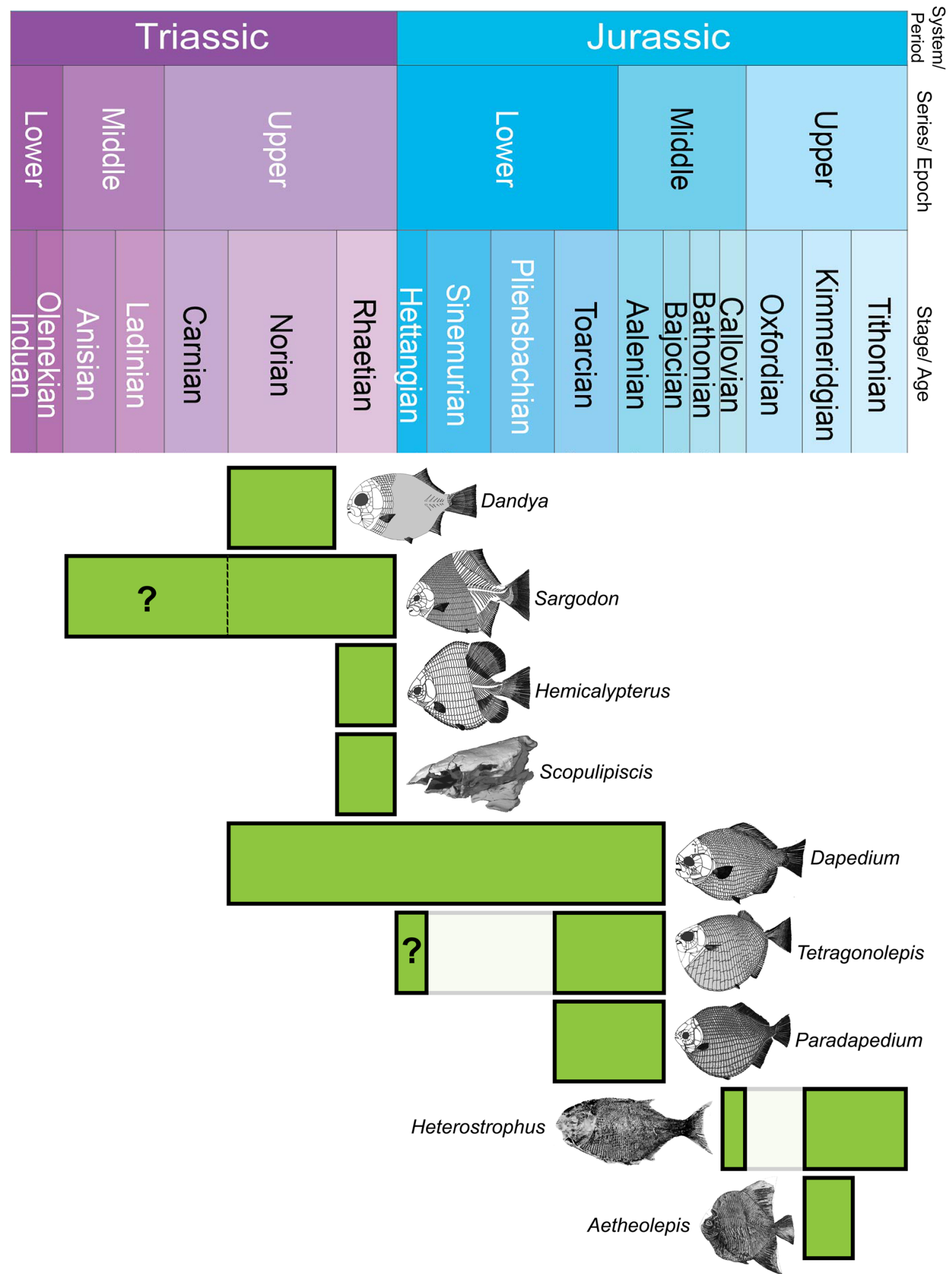

Fig. 7 Stratigraphic ranges of the nine genera assigned to Dapediidae, resolved at stage level. Compiled from the following sources: Dandya: Tintori 1983; Gorjanović-Kramberger 1905; Schultz 2013. Sargodon: Kear et al. 2010 and references therein; Boni 1937; Tintori 1983, 1998; Chalupová 2009; Godefroit et al. 1998; Boulvain et al. 2000; Schultz 2013; Korneisel et al. 2015; Nordén et al. 2015. Hemicalypterus: Gibson 2015. Scopulipiscis: Latimer and Giles 2018. Dapedium: Gorjanović-Kramberger 1905; Godefroit et al. 1998; Maxwell and López-Arbarello 2018; Schultz 2013; Thies and
Waschkewitz 2015; Thies and Hauff 2011; Tintori 1983. Tetragonolepis: Bandyopadhyay et al. 2010; Bassani 1886; Münster 1841; Corroy 1934; Delsate et al. 2002; Thies 1991; Jain and Roychowdhury 1987; Prasad and Manhas 2007; Jain 1973; Boulvain et al. 2000. Paradapedium: Bandyopadhyay et al. 2010; Prasad and Manhas 2007; Jain 1973; Jain and Roychowdhury 1987. Heterostrophus: Hudson and Martill 1991; Lambers 1999. Aetheolepis: Bean 2006; Woodward 1895b; Veevers 2000. Question marks refer to unfigured or questionable reports 
that its maxilla is toothless. The body size (about $45 \mathrm{~cm}$ in fullbody length) of the two species of Heterostrophus described by Woodward (1929) is much larger than that of the Úrkút dapediid. Nevertheless, Heterostrophus is very similar to Dapedium in the proportions of the squamation, and in general body shape, but differs in its stratigraphical range (see Fig. 7).

Aetheolepis has a much more diamond-shaped body and different fin proportions, compared to the Úrkút dapediid. Aetheolepis bears ganoid scales on the anterior half of the body, but amioid-type scales posteriorly (Gibson 2016), unlike V.10279.

Among the general characters of Dapedium, the hypsisomatic body, the interlocking rhomboidal ganoid scales, the relatively small mouth and the hem-shaped anal fins are visible on V.10279. Thies and Waschkewitz (2015) summarised the diagnostic features for Dapedium (amended from Wenz 1967 and Thies and Hauff 2011), of which only one can be observed on V.10279: the number of branchiostegal rays between four and eight.

V.10279 is slightly deformed rostrocaudally due to diagenesis, and/or post-lithification stress. This makes the taxonomically important characters hard to observe clearly in some areas (e.g. in the nasal region). Nonetheless, body shape of V.10279 falls well within the morphological range of Dapedium, since the genus shows variability in body shape, specimens could be fusiform, ellipsoidal or even cycloidal (Thies, pers. comm.). The Toarcian age of the specimen falls into the known range of Dapedium.

Measurements were taken on the scales of V.10279-A. Thies and Waschkewitz (2015) measured four areas of the squamation in various species of Dapedium, used here to compare with V.10279. The three measured areas of V.10279-A are not the same as those of Thies and Waschkewitz (2015), because our aim was to demonstrate the variability of scale proportions of the Úrkút specimen. For this reason, our method of using the measurements is also different from that of Thies and Waschkewitz (2015). The highest (or deepest) measured scales of V.10279-A are positioned on the posterior flank, near to the lateral line. The results (Fig. 6) show that the length/height $(1 / \mathrm{h})$ ratio of the scales slightly decreases posteriorly. No $1 / \mathrm{h}$ measurements of the squamation were taken in dapediid genera with body shape similar to Dapedium (Paradapedium, Tetragonolepis, Dandya), but figures of Jain (1973) and Tintori (1983) suggest that $\mathrm{l} / \mathrm{h}$ ratio in these genera sharply decreases dorsoventrally (i.e. the highest scales are positioned on or near to the belly region). Heterostrophus shows very similar scale proportions to that of Dapedium, with slight variability in different areas of the body surface, but the Úrkút dapediid is excluded from Heterostrophus for other reasons (see above). No information of the squamation of Scopulispiscis is available.
In summary, the reasons discussed above provide a solid basis to refer V.10279 to Dapedium. However, as preservation hinders observation of some diagnostic features, an assignment to any species is not attempted, until other specimens provide additional data.

\section{Discussion}

Overview of the fossil record and stratigraphic distribution of dapediids

Here, we discuss the occurrences and stratigraphic range of each of the nine genera assigned to Dapediidae by Thies and Hauff (2011), Gibson (2016) and Latimer and Giles (2018).

The small bodied Dandya (first described as Spaniolepis by Gorjanović-Kramberger 1905) has been reported from the Norian of Lombardy (Italy) (Tintori 1983) and Salzburg (Austria) (Gorjanović-Kramberger 1905).

Sargodon has been reported from several sites of Europe. Boni (1937) assigned molariform teeth to Sargodon from Rhaetian strata of northern Italy. Further isolated teeth of Sargodon are recorded from the Rhaetian beds of England, France and Germany (Tintori 1983). Chalupová (2009) figured both molariform and incisiform teeth assigned to Sargodon tomicus from the Rhaetian of Slovakia. Rhaetian beds of Syren (Luxembourg) also yielded isolated teeth of $S$. tomicus (Godefroit et al. 1998). S. tomicus is known from the Rhaetian Mortinsart Formation of Lorainne (Belgium) (Boulvain et al. 2000). Storrs (1994), Korneisel et al. (2015) and Nordén et al. (2015) also reported Sargodon from the Rhaetian of England. Tintori (1983) reported well-preserved specimens of S. tomicus from the Norian of Lombardy. From older strata, Kear et al. (2010) reported unfigured specimens of Sargodon from the Middle-Upper Triassic (upper Anisian to lowermost Carnian) Jilh Formation of Saudi Arabia, but this occurrence, possibly the oldest one for the whole group, remains doubtful.

Hemicalypterus is only known from the Upper Triassic (Rhaetian) part of the Chinle Group in southeastern Utah, USA (Schaeffer 1967; Gibson 2015, 2016).

Scopulipiscis is a large-sized (approximate body length of $2 \mathrm{~m}$ ) dapediid reported from the Upper Triassic (Rhaetian) of the Kössen Formation at Schesaplana, Grisons, Switzerland (Latimer and Giles 2018).

The Úrkút occurrence of Dapedium is in accordance with the abundance of the genus in the Toarcian. Maxwell and López-Arbarello (2018) recognises 15 valid species within the genus, ranging from the Upper Triassic (Norian) to the Middle Jurassic (Aalenian) (see Maxwell and LópezArbarello 2018, table 1 and references therein). Thus, the Norian to Aalenian range of Dapedium is well-established from a remarkable fossil record in Lagerstätten and 
formations enabling exceptional preservation (Zorzino Limestone, Blue Lias, Posidonia Shale and Opalinus Clay).

Tetragonolepis has been often synonymized with Dapedium, especially in works dating back to the nineteenth century. Evaluation of these reports is extremely difficult and some confusion is apparent (e.g. see synonymy lists of Woodward 1895a and Schultz 2013). Here, we follow Thies (1991), who considers Tetragonolepis as a distinct genus with two valid species, $T$. semicincta and T. oldhami, known from the Toarcian to the ?Aalenian (Jain and Roychowdhury 1987; Jain 1973; Thies 1991; Prasad and Manhas 2007; Bandyopadhyay et al. 2010). Tetragonolepis sp. was reported (but not figured) from the Toarcian Grandcourt Formation of Lorainne, Belgium (Boulvain et al. 2000). A questionable report of Tetragonolepis from the Hettangian of Fontenoille (Belgium) is based on a single isolated tooth (Delsate et al. 2002, pl. 15, fig. c).

Paradapedium is only known from the upper Kota Formation (Toarcian-?Aalenian) of India (Jain 1973; Jain and Roychowdhury 1987; Prasad and Manhas 2007; Bandyopadhyay et al. 2010).

Eastman (1914) described specimens of the genus Heterostrophus, originally under the name of Homoeolepis. Heterostrophus is known from the Callovian (Lower Oxford Clay, England; Hudson and Martill 1991), and, with a stratigraphical gap for the Oxfordian, also from the upper Kimmeridgian-lower Tithonian (Solnhofen, Germany; Lambers 1999).

Aetheolepis was described from a single locality, the Kimmeridgian Talbragar beds of Australia (Woodward 1895b).

The fossil record of Dapedium in particular, and dapediids in general, is clearly biased by the Lagerstätten effect, with the majority of occurrences of articulated specimens known from formations amenable to exceptional preservation. Apart from taphonomic bias, the predominance of European occurrences may also represent an additional bias introduced by geographically uneven sampling, with Old World localities with a long history of study and superior sampling effort heavily overrepresented. Australia, India and the USA only contribute scattered localities to the known geographic distribution of the group; thus, the notion of a European (i.e. westernmost Tethyan) centre of dapediid evolution may represent an artefact caused by sampling bias. However, the recently described Ya Ha Tinda Lagerstätte in the Toarcian of Alberta (western Canada) has not yielded dapediid remains (Martindale et al. 2017).

Remarkably, the confirmed range end points of dapediids are also related to Lagerstätten, as the first undisputed occurrence of the group is from the Norian Zorzino Limestone and the youngest occurrence is recorded from the Kimmeridgian-Tithonian Plattenkalk of Solnhofen. Also notable, however, that the Toarcian Strawberry Bank Formation Lagerstätte (Somerset, UK) yielded a various actinopterygian taxa, but up to now, dapediids have not been reported from the site (Williams et al. 2015). This formation would be expected to yield dapediids, as it is coeval with the Posidonia Shale and paleogeographically not far from it; therefore, the lack of dapediid finds in the Strawberry Bank fossil record is somewhat unexpected. It may be accounted for by collection failure, as the fossil locality is now buried and collecting is no longer possible. With regard to the above, a significant gap in the fossil record of dapediiforms in the Middle Jurassic may not be surprising. This likely relates to the overall lack of fossil localities preserving whole-bodied actinopterygian specimens (Smithwick and Stubbs 2018). The lack of Bajocian-Bathonian finds predicts further discoveries, as Heterostrophus and Aetheolepis are unquestionable members of the order Dapediiformes.

Dapediids and the end-Triassic and Toarcian mass extinctions

According to the available data, five known dapediid genera existed in the Late Triassic: Dandya, Sargodon, Hemi-calypterus, Scopulipiscis and Dapedium. Based on the fossil record, among these taxa, only Dapedium survived the end-Triassic mass extinction. The other dapediid genera Tetragonolepis, Paradapedium, Heterostrophus and Aetheolepis originated in the Jurassic, i.e. after the end-Triassic mass extinction (Fig. 7).

The end-Triassic mass extinction is considered as one of the five biggest mass extinction events, with data suggesting extinction levels of up to $80 \%$ among the marine skeletonized invertebrate species lost (Sepkoski 1996). Synchronicity of mass extinction and volcanism of the Central Atlantic Magmatic Province in the TriassicJurassic boundary is well-established (Pálfy et al. 2002; Pálfy 2003). Large amount of carbon dioxide released from volcanoes resulted in extreme greenhouse warming, ocean acidification and anoxia (Hautmann 2004, 2012; Hautmann et al. 2008; van de Schootbrugge et al. 2009; Pálfy and Kocsis 2014). Moreover, volcanism might have caused sudden warming of deep waters as well that resulted in methane-release (Pálfy 2003). Both marine and terrestrial communities showed drastic changes across the Triassic-Jurassic boundary (Benton 1995).

The radiation of Dapedium occurred after the end-Triassic mass extinction (Smithwick 2015; Smithwick and Stubbs 2018). A compilation of Early Jurassic occurrences of Dapedium from Europe shows that these fishes were widespread in the northwest European epicontinental sea in this epoch. Their success could be related to the generalistdurophagous feeding strategy and the deep, flattened body shape (Thies and Hauff 2011; Fletcher et al. 2017; Stumpf et al. 2017; Smithwick and Stubbs 2018), which provided a wider range of available prey and high manoeuvrability for these fishes after the end-Triassic mass extinction (Bellwood and Hoey 2004; Smithwick 2015). Ammonites could have 
served as a food source in near surface waters for generalistdurophagous (and scavenger) dapediids, including the genus Dapedium, before and after the end-Triassic mass extinction. This is partially supported by a Dapedium individual fossilised in the body chamber of a Lytoceras sp. specimen, found in the Toarcian Posidonia Shale (Thies and Hauff 2011), and suggested as proof of scavenging feeding strategy, rather than predation. This inference is in agreement with Andrew et al. (2010), who suggested that fish could not easily manipulate ammonite shells to remove the soft internal parts.

Smithwick and Stubbs (2018) provide the most recent comprehensive analysis of fishes through the end-Triassic mass extinction event and show little change across the boundary in terms of diversity, body shape or ecomorphology in actinopterygians. One major change, however, occurred in dapediids: after the end-Triassic mass extinction, Dapedium was shown to radiate into a novel area of functional morphospace by developing a unique jaw morphology not seen in any other Early Jurassic fish genus (see also in Smithwick and Stubbs 2018, fig. 2). This finding supports that the jaw and the feeding mode were important factors in their survival and radiation after the extinction event.

We suggest that the effects of the end-Triassic mass extinction may also be reflected in other changes in the anatomy of dapediid fishes. Extinction of taxa with light squamation (i.e. incomplete body squamation, thin and/or non-ganoin squamation, or scales only poorly ornamented by ganoine), and the survival of Dapedium, a form with thick, full-body ganoid squamation in the end of the Triassic is a clearly emerging pattern. A possible reason for the extinction of some taxa could have been the less effective protection of the incomplete and light squamation against predators. Ganoid scales are heavy and difficult to penetrate (penetration resistance of scales of living ganoid taxa has been investigated by, e.g. Bruet et al. 2008; Song 2011; Sherman et al. 2016); therefore, bearing a well-closing, ganoid scalearmour would also have been likely to be a successful strategy against predators. After the end-Triassic mass extinction, marine reptiles, such as sauropterygians, ichthyosaurians and thalattosuchians, played important roles in marine ecosystems and could have been potential predators preying on dapediid fishes (Thorne et al. 2011; Stubbs and Benton 2016).

Scales of Dandya were ornamented by only scattered, small spots of ganoine, rather than a continuous ganoinelayer (Tintori 1983), scales of Sargodon become extremely thin posteriorly (Tintori 1983) and the posterior flank of Hemicalypterus is devoid of scales (Gibson 2016). As Fig. 7 illustrates, only Dapedium, a genus with full-body ganoid squamation, survived the end-Triassic mass extinction.

Another possible reason for the extinction of Sargodon and Hemicalypterus could have been their food preference. Dentition of Sargodon included bifid incisors on the premaxilla and dentary, usually with a V-shaped notch
(Tintori 1983) and grinding palatal teeth. This indicates that Sargodon fed on invertebrates, possibly using the bifid marginal teeth to pick up shelly invertebrates (e.g. gastropods, bivalves, brachiopods) from the substrate, then crushed their hard exoskeletons with the grinding palatal teeth (Tintori 1983; Gibson 2015). Sixty-three percent of marine invertebrate taxa became extint in the end-Triassic mass extinction (Alroy 2008). Seventy-one percent of articulated brachiopod genera and $40 \%$ of marine bivalve genera became extinct, while gastropods also suffered significant losses (Hautmann et al. 2008). Such great loss of invertebrate taxa, their food source could have been an important driver in the extinction of Sargodon in the end-Triassic. Hautmann et al. (2008) noted that several bivalve families switched from aragonitic to calcitic shells across the Triassic-Jurassic boundary. The shift from weaker aragonite to harder calcite skeleton in its prey animals may also have contributed to the demise of Sargodon.

Hemicalypterus is regarded as a herbivore with specialised, multicuspid dentition that probably exploited a nektobenthic feeding niche by using its multicuspid teeth to harvest algae or other attached plants and organisms from a rocky substrate (Gibson 2015). These food sources may be sensitive to acidification and anoxia, both thought to have occured in the endTriassic, leading to decrease of food source during the mass extinction event. A specialist feeder is more vulnerable to rapid environmental changes than a generalist durophage (Smithwick 2015 and references therein), possibly leading to the extinction of Hemicalypterus, as there is no record of Hemicalypterus after the end-Triassic mass extinction event (Gibson 2015).

The single available specimen of Scopulipiscis is a neurocranium with associated dermal elements (Latimer and Giles 2018); hence, no teeth and scales are preserved, precluding inferences about its feeding habit. Its extremely large size (c. $2 \mathrm{~m}$ in length) allows speculation that selectivity against large size may have been a factor in the end-Triassic extinction that also wiped out Sargodon, which reached $1 \mathrm{~m}$ in full-body length (Tintori 1983).

A generalist-durophagous feeding strategy could have provided a wider range of prey for taxa with simple, unicuspid, styliform teeth such as Dapedium, Tetragonolepis and Paradapedium during and after end-Triassic mass extinction. This allowed Dapedium to radiate and fill vacant ecospaces, previously occupied by taxa that vanished at the end-Triassic mass extinction (Bellwood and Hoey 2004; Smithwick 2015; Smithwick and Stubbs 2018). Moreover, the laterally flattened, deep (hypsisomatic) body shape of Dapedium indicates that these fishes were well-adapted to maneuvering (PoyatoAriza 2005; Fletcher et al. 2017; Stumpf et al. 2017). The same reasons may explain the emergence of Tetragonolepis and Paradapedium (taxa similar to Dapedium in dentition and 
body shape) in the Jurassic. Although dental evidence might suggest ecological niche overlap, differences in morphological adaptations in Dapedium and Tetragonolepis (as well as the Early Jurassic neopterygian Lepidotes, which is also considered as a facultative durophagous feeder) are likely connected with their foraging mode and, consequently, in the segregation of available food resources (Stumpf et al. 2017). After the end-Triassic mass extinction, bifid marginal teeth reoccurred in various Liassic Dapedium species, such as $D$. politum, D. radiatum, D. orbis, D. dorsalis, D. colei and D. granulatus (Woodward 1895a; Thies and Hauff 2011), suggesting that changes occurred in the diet of dapediids.

A third possible reason for the disappearance of some dapediiforms in the end-Triassic is the global reef crisis driven by climate warming. The end-Triassic warming and possible ocean acidification triggered a collapse of metazoan reefs (Hönisch et al. 2012; Pandolfi and Kiessling 2014). 117 reefs were recorded in the Norian-Rhaetian (Kiessling et al. 1999), and the sudden disappearance of these reefs is one of the most obvious indicators for the biological crisis at the Triassic-Jurassic boundary (Pálfy and Kocsis 2014). The collapse of the reef ecosystems as habitats could have been a major driver for the extinction of the dapediiform taxa, less capable for adaptation.

Dapedium is the only known dapediid genus surviving the end-Triassic extinction (Fig. 7), and generic diversity of the group only approached the Rhaetian level in the Toarcian, where two other genera (Tetragonolepis and Paradapedium) are also recorded. Dapedium is not only the longest-ranging, but also the most speciose genus of the group, with exceptional records of both the Sinemurian and Toarcian. Although the Lagerstätten effect may distort the specieslevel diversity history, it is remarkable that all three genera known from the Toarcian (Dapedium, Tetragonolepis and Paradapedium) survived into the Aalenian (Fig. 7). The Jenkyns event (or Toarcian Oceanic Anoxic Event) clearly contributed to the exceptional preservation in the Posidonia Shale and correlative anoxic sediments (including the Úrkút Manganese Ore Formation), yet the coeval cascade of environmental changes did not cause genus-level extinction among the dapediids. The Jenkyns event is well known to be an episode of rapid environmental changes that bears many similarities to the end-Triassic event. Volcanism of the Karoo-Ferrar large igneous province is thought to have triggered global warming, changes in ocean chemistry, including anoxia, possible ocean acidification, and a secondorder extinction event (Jenkyns 1988, 2010; Harries and Little 1999; Pálfy et al. 2002; Hönisch et al. 2012). In contrast to the end-Triassic event, however, the Jenkyns event did not cause genus extinction among the dapediids. This suggests that acquired traits and adaptations evolved during the preceding multi-stressor event may have helped surviving the next crisis during the Toarcian.

\section{Conclusions}

The Dapedium specimen from Úrkút is the first articulated Mesozoic fish body fossil from Hungary that is described in detail. The occurrence of Dapedium in the Úrkút Manganese Ore Formation represents the first report of the order Dapediiformes from Hungary. The preserved cranium reveals important characters, although species-level identification is hindered by suboptimal preservation of some diagnostic features. The general body morphology, details of the squamation and preserved features of the skull allow its unambiguous assignment to Dapedium and distinguish the Úrkút specimen from other dapediiform genera, in agreement with its Toarcian age. The Úrkút locality extends the known geographic distribution of the genus and the order.

We speculate that the disappearance of exclusively Late Triassic dapediid genera coincided with the end-Triassic extinction event, although a patchy fossil record makes this difficult to determine unambiguously. Selective extinction or survival of dapediid genera during the endTriassic event was likely related to their feeding strategy and squamation, and may also be connected to the global reef crisis.

The exceptional Toarcian fossil record of dapediids is likely explained by the Lagerstätten effect. In contrast to the end-Triassic event, the Jenkyns event or T-OAE caused no genus-level extinction among the dapediids as all three genera known from the Toarcian survived into the Aalenian. The difference may be explained by resilience from adaptation evolved during the first of these two similar, multi-stressor crises. The lack of BajocianBathonian occurrences serves as a reminder of the incompleteness of dapediid fossil record which leaves a degree of uncertainty in any reconstruction of their diversity history but underlines the significance of each new find.

Acknowledgements Open access funding provided by Eötvös Loránd University (ELTE). We thank Lynne Bean, Lóránt Bíró, John Clarke, Martin Ebert and István Főzy for providing literature sources, photographs and helpful information. We are grateful to Emese Réka Bodor and Detlev Thies for their constructive suggestions. We also thank László Makádi and Bálint Szappanos for their technical assistance. Contributors to the Paleobiology Database are acknowledged here for compiling occurrence data from relevant literature. Constructive reviews by Lionel Cavin and an anonymous reviewer have greatly improved the manuscript.

Funding information Our work was supported by the National Research, Development and Innovation Office (Grant No. K116665), the Hungarian Natural History Museum, the Eötvös Loránd University and the ELTE Dinosaur Research Group. This is MTA-MTM-ELTE Paleo contribution no. 271.

\section{Compliance with ethical standards}

Conflict of interest The authors declare that they have no conflict of interest. 
Open Access This article is distributed under the terms of the Creative Commons Attribution 4.0 International License (http:// creativecommons.org/licenses/by/4.0/), which permits unrestricted use, distribution, and reproduction in any medium, provided you give appropriate credit to the original author(s) and the source, provide a link to the Creative Commons license, and indicate if changes were made.

\section{References}

Alroy, J. (2008). Dynamics of origination and extinction in the marine fossil record. Proceedings of the National Academy of Science, 105, 11536-11542.

Andrew, C., Howe, P., Paul, C. R., \& Donovan, S. K. (2010). Fatally bitten ammonites from the lower Lias Group (Lower Jurassic) of Lyme Regis, Dorset. Proceedings of the Geological Society of Yorkshire, 58(2), 81-94. https://doi.org/10.1144/pygs.58.1.276.

Bandyopadhyay, S., Gillette, D. G., Ray, S., \& Sengupta, D. P. (2010). Osteology of Barapasaurus tagorei (Dinosauria: Sauropoda) from the early Jurassic of India. Palaeontology, 53(3), 533-569.

Bassani, F. (1886). Sui fossili e sull'età degli schisti bituminosi triasici di Besano in Lombardia (Vol. 29, pp. 15-72). Atti della Società Italiana di Scienze Naturali.

Bean, L. B. (2006). The leptolepid fish Cavenderichthys talbragarensis (Woodward, 1895) from the Talbragar Fish Bed (Late Jurassic) near Gulgong, New South Wales. Records of the Western Australian Museum, 23, 43-76.

Bellwood, D. R., \& Hoey, A. (2004). Feeding in Mesozoic fishes: a functional perspective. 639-649. In G. Arratia \& A. Tintori (Eds.), Mesozoic fishes 3: systematics, paleoenvironments and biodiversity (p. 649). München: Verlag Dr. Friedrich Pfeil.

Benton, M. J. (1995). Diversification and extinction in the history of life. Science, 268, 52-58.

Bíró, L. (2014). Az úrkúti mangánérc-bányászat fúrásainak sztratigráfiai ujraértékelése (The stratigraphic re-evaluation of the drillings of the manganese ore mining at Úrkút). Földtani Közlöny, 144(1), 3-14. [in Hungarian]

Boni, A. (1937). Vertebrati Retici italiani. Memorie della Accademia Nazionale dei Lincei, series 6, 6(10), 521-719.

Boulvain, F., Belanger, I., Delsate, D., Dosquet, D., Ghysel, P., Godefroit, P., Laloux, M., Roche, M., Teerlynck, H., \& Thorez, J. (2000). New lithostratigraphical, sedimentological, mineralogical and palaeontological data on the Mesozoic of Belgian Lorainne: a progress report. Geologica Belgica, 3(1-2), 3-33.

Bruet, B. J. F., Song, J., Boyce, M. C., \& Ortiz, C. (2008). Materials design principles of ancient fish armour. Nature Materials, 7, 748756. https://doi.org/10.1038/nmat2231.

Chalupová, B. (2009). Rétske žraloki a ryby z fatranského súvrstvia (profil Kardolína, Belianska Tatry, Slovensko). Mineralia Slovaca, 41, 283-290.

Cope, E. D. (1872). Observations on the systematic relations of the fishes. In Proceedings of the American Association for the Advancement of Science (Vol. 20, pp. 317-343).

Cope, E. D. (1887). Zittel's manual of palaeontology. American Naturalist, 21, 1014-1019.

Corroy, G. (1934). Les poissons et les reptiles du Muschelkalk et du Rhetien de Basse-Provence. Bulletin de la Societe geologique de France 3, 5(5-6), 475-483.

Cseh-Németh, J. (1966). A mangánérc. (The manganese ore). In B. Jantsky (Ed.), Ásványtelepeink Földtana (pp. 120-142). Budapest: Müszaki Könyvkiadó. [in Hungarian]

Delsate, D., Duffin, C. J., \& Weis, R. (2002). A new microvertebrate fauna from the Middle Hettangian (Early Jurassic) of Fontenoille (province of Luxembourg, south Belgium). In Memoirs of the Geological Survey of Belgium (Vol. 48). Brussel: Geological Survey of Belgium $84 \mathrm{pp}$.

Dulai, A., Suba, Z., \& Szarka, A. (1992). Toarci (alsójura) szervesanyagdús fekete pala a mecseki Réka-völgyben. (Toarcian (Lower Jurassic) organic-rich black shale in the Réka Valley (Mecsek Hills, Hungary)). Földtani Közlöny, 122(1), 67-87. [in Hungarian]

Eastman, C. R. (1914). Catalog of fossil fishes in the Carnegie Museum, Part 3, Descriptive catalog of fossil fishes from the lithographic stone of Solenhofen, Bavaria, France - Memoirs of the Carnegie Museum, 6(7), 389-423.

Fletcher, T., Altringham, J., Peakall, J., Wignall, P., \& Dorrell, R. (2017). Hydrodynamics of fossil fishes. Proceedins of the Royal Society B, 281, 20140703. https://doi.org/10.1098/rspb.2014.0703.

Főzy, I., \& Szente, I. (2014). Fossils of the Carpathian Region. Bloomington: Indiana University Press 508 p.

Gibson, S. Z. (2015). Evidence of a specialized feeding niche in a Late Triassic ray-finned fish: evolution of multidenticulate teeth and benthic scraping in †Hemicalypterus. The Science of Nature, 102(10). https://doi.org/10.1007/s00114-015-1262-y.

Gibson, S. Z. (2016). Redescription and phylogenetic placement of $\dagger$ Hemicalypterus weiri Schaeffer, 1967 (Actinopterygii, Neopterygii) from the Triassic Chinle Formation, Southwestern United States: new insights into morphology, ecological niche, and phylogeny. PLoS One, 11(9), e0163657. https://doi.org/10.1371/ journal.pone.0163657.

Godefroit, P., Cuny, G., Delsate, D., \& Roche, M. (1998). Late Triassic vertebrates from Syren (Luxembourg). Neues Jahrbuch für Geologie und Paläontologie, Abhandlungen, 210(3), 305-343.

Gorjanović-Kramberger, K. (1905). Die obertriadische Fischfauna von Hallein in Salzburg. Beiträge zur Paläontologie und Geologie Österreich-Ungarns und des Orients, 18, 193-224.

Grande, L. (2010). An empirical synthetic pattern study of gars (Lepisosteiformes) and closely related species, based mostly on skeletal anatomy. The resurrection of Holostei (Vol. 10 (2A), p. 863). American Society of Ichthyologist and Herpetologists. supp. Issue of Copeia.

Grasselly, G., \& Pantó, G. (1988). Rare earth elements in the manganese deposit of Úrkút (Bakony Mountains, Hungary). Ore Geology Reviews, 4, 115-124. https://doi.org/10.1016/0169-1368(88)90007-8.

Haas, J. (2012). Influence of global, regional, and local factors on the genesis of the Jurassic manganese ore formation in the Transdanubian Range, Hungary. Ore Geology Reviews, 47, 77-86.

Harries, P. J., \& Little, C. T. S. (1999). The early Toarcian (Early Jurassic) and the Cenomanian-Turonian (Late Cretaceous) mass extinctions: similarities and contrasts. Palaeogeography, Palaeoclimatology, Palaeoecology, 154, 39-66.

Hautmann, M. (2004). Effect of end-Triassic $\mathrm{CO}_{2}$ maximum on carbonate sedimentation and marine mass extinction. Facies, 50, 257-261.

Hautmann, M. (2012). Extinction: End-Triassic Mass Extinction. In eLS. Chichester. http://www.els.net. Accessed 1 Aug 2018: Wiley. https:// doi.org/10.1002/9780470015902.a0001655.pub3

Hautmann, M., Benton, M. J., \& Tomašových, A. (2008). Catastrophic ocean acidification at the Triassic-Jurassic boundary. Neues Jahrbuch für Geologie und Paläntologie, Abhandlungen, 249, 119-127.

Hönisch, B., Ridgwell, A., Schmidt, D. N., Thomas, E., Gibbs, S. J., Sluijs, A., Zeebe, R., Kump, L., Martindale, R. C., Greene, S. E., Kiessling, W., Ries, J., Zachos, J. C., Royer, D. L., Barker, S., Marchitto, T. M., Jr., Moyer, R., Pelejero, C., Ziveri, P., Foster, G. L., \& Williams, B. (2012). The geological record of ocean acidification. Science, 335, 1058-1063. https://doi.org/10.1126/science.1208277.

Hudson, J. D., \& Martill, D. M. (1991). The Lower Oxford Clay: production and preservation of organic matter in the Callovian (Jurassic) of central England. In R. V. Tyson \& T. H. Pearson (Eds.), Modern and Ancient Continental Shelf Anoxia. Geological Society Special Publication No (Vol. 58, pp. 363-379). 
Jain, S. L. (1973). New specimens of Lower Jurassic holostean fishes from India. Palaeontology, 16, 149-177.

Jain, S. L., \& Roychowdhury, T. (1987). Fossil vertebrates from the Pranhita-Godavari Valley (India) and their stratigraphic correlation. In G. D. McKenzie (Ed.), Gondwana six: stratigraphy, sedimentology, and paleontology. Washington, D. C.: American Geophysical Union. https://doi.org/10.1029/GM041p0219.

Jenkyns, H. C. (1988). The early Toarcian (Jurassic) anoxic event: stratigraphic, sedimentary, and geochemical evidence. American Journal of Science, 288, 101-151.

Jenkyns, H. C. (2010). Geochemistry of oceanic anoxic events. Geochemistry Geophysics Geosystems, 11. https://doi.org/10.1029/ 2009GC002788.

Kear, B. P., Rich, T. H., Vickers-Rich, P., Ali, A. M., Al-Mufarrih, Y. A., Matari, A. H., Al-Masary, A. M., \& Halawani, M. A. (2010). A review of aquatic vertebrate remains from the Middle-Upper Triassic Jilh Formation of Saudi Arabia. Proceedings of the Royal Society of Victoria, 122(1), 1-8 ISSN 0035-9211.

Kiessling, W., Flügel, E., \& Golonka, J. (1999). Paleoreef maps: evaluation of a comprehensive database on Phanerozoic reefs. American Association of Petroleum Geologists Bulletin, 83, 1552-1587.

Korneisel, D., Gallois, R. W., Duffin, C. J., \& Benton, M. J. (2015). Latest Triassic marine sharks and bony fishes from a bone bed preserved in a burrow system, from Devon, UK. Proceedings of the Geologists' Association, 126(1), 130-142. https://doi.org/10.1016/j.pgeola.2014. 11.004 .

Lambers, P. H. (1999). The actinopterygian fish fauna of the Late Kimmeridgian and Early Tithonian "Plattenkalke" near Solnhofen (Bavaria, Germany): state of the art (Vol. 78, pp. 215-229). Geologieen Mijnbouw.

Latimer, A. E., \& Giles, S. (2018). A giant dapediid from the Late Triassic of Switzerland and insights into neopterygian phylogeny. Royal Society Open Science, 5, 180497. https://doi.org/10.1098/rsos. 180497.

Lehman, J. P. (1966). Actinopterygii. In J. Piveteau (Ed.), Traité de Paléontologie. Vol. 4(3), Actinoptérygiens, Dipneustes, Crossoptérygiens (pp. 1-242). Paris: Masson.

Lombardo, C., \& Tintori, A. (2005). Feeding specializations in Late Triassic fishes. Annali Università Ferrara, Museologia Scientifica e Naturalistica, special volume, 2005, 25-31.

Martindale, R. C., Them, T. R., Gill, B. C., Marroquín, S. M., \& Knoll, A. H. (2017). A new Early Jurassic (ca. $183 \mathrm{Ma}$ ) fossil Lagerstätte from Ya Ha Tinda, Alberta, Canada. Geology, 45(3), 255-258.

Maxwell, E. E., \& López-Arbarello, A. (2018). A new species of the deep-bodied actinopterygian Dapedium from the Middle Jurassic (Aalenian) of southwestern Germany. PeerJ, 6, e5033. https://doi. org/10.7717/peerj.5033 .

Müller, J. (1844). Über den Bau und die Grenzen der Ganoiden und über das natürliche System der Fische (pp. 416-422). Berlin: Bericht Akademie der Wissenschaften.

Müller, T., Price, G. D., Bajnai, D., Nyerges, A., Kesjár, D., Raucsik, B., Varga, A., Judik, K., Fekete, J., May, Z., \& Pálfy, J. (2017). New multiproxy record of the Jenkyns Event (also known as the Toarcian Oceanic Anoxic Event) from the Mecsek Mountains (Hungary): Differences, duration and drivers. Sedimentology, 64(1), 66-86.

Münster, G. (1841). Beiträge zur Geognosie und Petrefacten-Kunde des südöstlichen Tirols vorzüglich der Schichten von St. Cassian. Beiträge zur Petrefacten-Kunde, 4, 1-152.

Nordén, K. K., Duffin, C. J., \& Benton, M. J. (2015). A marine vertebrate fauna from the Late Triassic of Somerset, and a review of British placodonts. Proceedings of the Geologists' Association, 126, 564 581. https://doi.org/10.1111/j.1096-3642.1994.tb00319.x.

Pálfy, J. (2003). Volcanism of the Central Atlantic Magmatic Province as a potential driving force in the end-Triassic mass extinction. The Central Atlantic Magmatic Province: Insights from Fragments of
Pangea. Geophysical Monograph 136, 255-267. https://doi.org/ 10.1029/136GM014.

Pálfy, J., \& Kocsis, Á. (2014). Volcanism of the Central Atlantic magmatic province as the trigger of environmental and biotic changes around the Triassic-Jurassic boundary. In G. Keller \& A. C. Kerr (Eds.), Volcanism, Impacts, and Mass Extinctions: Causes and Effects (Vol. 505, pp. 245-261). Boulder: Geological Society of America Special Paper. https://doi.org/10.1130/2014.2505(12).

Pálfy, J., Smith, P. L., \& Mortensen, J. K. (2002). Dating the end-Triassic and Early Jurassic mass extinctions, correlative large igneous provinces, and isotopic events. Geological Society of America, Special Paper, 356, 523-532.

Pandolfi, J. M., \& Kiessling, W. (2014). Gaining insights from past reefs to inform understanding of coral reef response to global climate change. Current Opinion in Environmental Sustainability, 7, 52 58. https://doi.org/10.1016/j.cosust.2013.11.020.

Pantó, G., Demény, A., \& Polgári, M. (1996). Genesis of secondary Mnoxide ores in the Úrkút deposit, Hungary. Mineralium Deposita, 31, 238-241. https://doi.org/10.1007/BF00204030.

Pászti, A. (2004). Halmaradványok az Úrkúti Mangánérc Formáció képződményeiböl. (Fish remains from the Úrkút Manganese Ore Formation). Bányászati és Kohászati Lapok - Bányászat, 137(6), 46-47. [in Hungarian]

Polgári, M., Okita, P. M., \& Hein, J. R. (1991). Stable isotope evidence for the origin of the Urkut Manganese Ore Deposit, Hungary. Journal of Sedimentary Research, 61(3), 384-393. https://doi.org/ 10.1306/D426771C-2B26-11D7-8648000102C1865D.

Polgári, M., Szabó, Z., \& Szederkényi, T. (2000). Mangánércek Magyarországon - Grasselly Gyula akadémikus emlékére. (Manganese Ores in Hungary - In commemoration of professor Gyula Grasselly.) Szeged: MTA Szegedi Akadémiai Bizottsága 652 p. [in Hungarian]

Polgári, M., Tóth, M., Dobosi, G., Bajnóczy, B., Szabó, Z., \& Vigh, T. (2004). Az úrkúti halmaradványokat tartalmazó konkréciók ásványos- éskémiai összetételének vizsgálata (Mineralogical and chemical investigations on the fish-including nodules of Úrkút). Bányászati és Kohászati Lapok -Bányászat, 137(6), 47-48. [in Hungarian]

Polgári, M., Hein, J. R., Vigh, T., Szabó-Drubina, M., Fórizs, I., Bíró, L., Müller, A., \& Tóth, A. L. (2012). Microbial processes and the origin of the Úrkút manganese deposit, Hungary. Ore Geology Reviews, 47, 87-109. https://doi.org/10.1016/j.oregeorev.2011.10.001.

Polgári, M., Hein, J. R., Németh, T., Pál-Molnár, E., \& Vigh, T. (2013). Celadonite and smectite formation in the Úrkút Mn-carbonate ore deposit (Hungary). Sedimentary Geology, 294, 157-163. https://doi. org/10.1016/j.sedgeo.2013.05.017.

Polgári, M., Hein, J. R., Bíró, L., Gyollai, I., Németh, T., Sajgó, C., Fekete, J., Schwark, L., Pál-Molnár, E., Hámor-Vidó, M., \& Vigh, T. (2016a). Mineral and chemostratigraphy of a Toarcian black shale hosting Mn-carbonate microbialites (Úrkút, Hungary). Palaeogeography, Palaeoclimatology, Palaeoecology, 459, 99-120. https://doi.org/10. 1016/j.palaeo.2016.06.030.

Polgári, M., Németh, T., Pál-Molnár, E., Futó, I., Vigh, T., \& Mojzsis, S. J. (2016b). Correlated chemostratigraphy of Mn-carbonate microbialites (Úrkút, Hungary). Gondwana Research, 29(1), 278289. https://doi.org/10.1016/j.gr.2014.12.002.

Poyato-Ariza, F. J. (2005). Pycnodont fishes: morphologic variation, ecomorphologic plasticity, and a new interpretation of their evolutionary history. In Bulletin of the Kitakyushu Museum of Natural History and Human History, Series A (Natural History) (Vol. 3, pp. 169-184).

Prasad, G. V. R., \& Manhas, B. K. (2007). A new Docodont mammal from the Jurassic Kota formation of India. Palaeontologia Electronica, 10(2), 7A $11 \mathrm{p}$.

Schaeffer, B. (1967). Late Triassic fishes from the southwestern United States. Bulletin of the American Museum of Natural History, 135, 285-342. 
Schootbrugge, B. van de, Quan, T. M., Lindström, S., Püttmann, W., Heunisch, C., Pross, J., Fiebig, J., Petschick, R., Röhling, H.-G., Richoz, S., Rosenthal, Y., \& Falkowski, P. G. (2009). Floral changes across the Triassic/Jurassic boundary linked to flood basalt volcanism. Nature Geoscience, 2, 589-594.

Schultz, O. (2013). Pisces. In W. Piller (Ed.), Catalogus Fossilium Austriae, Bd. 3. Wien: Verlag der Österreichischen Akademie der Wissenschaften $576 \mathrm{pp}$.

Sepkoski, J. (1996). Patterns of Phanerozoic extinction: a perspective from global data bases. In O. H. Walliser (Ed.), Global events and event stratigraphy in the Phanerozoic. Berlin: Springer.

Sherman, V. R., Yaraghi, N. A., Kisailus, D., \& Meyers, M. A. (2016). Microstructural and geometric influences in the protective scales of Atractosteus spatula. Journal of the Royal Society of Interface, 13, 20160595. https://doi.org/10.1098/rsif.2016.0595.

Smithwick, F. M. (2015). Feeding ecology of the deep-bodied fish Dapedium (Actinopterygii, Neopterygii) from the Sinemurian of Dorset, England. Palaeontology, 58, 293-311. https://doi.org/10.1111/pala.12145.

Smithwick, F. M., \& Stubbs, T. L. (2018). Phanerozoic survivors: Actinopterygian evolution through the Permo-Triassic and Triassic-Jurassic mass extinction events. Evolution, 72(2), 348-362.

Song, J. (2011). Multiscale materials design of natural exoskeletons: Fish armor. PhD thesis in Department of Material Science and Engineering, Massachusetts Institute of Technology.

Storrs, G. W. (1994). Fossil vertebrate faunas of the British Rhaetian (latest Triassic). Zoological Journal of the Linnean Society, 112, 217-259. https://doi.org/10.1111/j.1096-3642.1994.tb00319.x.

Stubbs, T. L., \& Benton, M. J. (2016). Ecomorphological diversifications of Mesozoic marine reptiles: the roles of ecological opportunity and extinction. Paleobiology, 42, 547-573. https://doi.org/10.1017/pab.2016.15

Stumpf, S., Ansorge, J., Pfaff, C., \& Kriwet, J. (2017). Early Jurassic diversification of pycnodontiform fishes (Actinopterygii, Neopterygii) after the end-Triassic extinction event: evidence from a new genus and species, Grimmenodon aureum. Journal of Vertebrate Paleontology, 37(4), 14 pages), e1344679. https://doi. org/10.1080/02724634.2017.1344679.

Szabó, Z., \& Grasselly, G. Y. (1980). Genesis of manganese oxide ore in the Úrkút basin, Hungary. In I. M. Varentsov \& G. Y. Grasselly (Eds.), Geology and Geochemistry of Manganese (Vol. 2, pp. 223236). Budapest: Akadémiai Kiadó.

Szabó, Z., Grasselly, G., \& Cseh-Németh, J. (1981). Some conceptual questions regarding the origin of manganese in the Úrkút deposit, Hungary. Chemical Geology, 34, 19-29. https://doi.org/10.1016/ 0009-2541(81)90068-1.

Thies, D. (1988). Dapedium pholidotum (Agassiz, 1832)? (Pisces, Actinopterygii) aus dem Unter-Toarcium NW-Deutschlands. Geologica et Palaeontologica, 22, 89-121.

Thies, D. (1991). The osteology of thebony fish Tetragonolepis semicincta Bronn 1830 (Actinopterygii, †Semionotiformes) from the Early Jurassic (lower Toarcian) of Germany. Geologica et Palaeontologica, 25, 251-297.
Thies, D., \& Hauff, R. B. (2008). A neotype for Dapedium caelatum Quenstedt, 1858 (Actinopterygii, Neopterygii, Semionotiformes) from the Early Jurassic (early Toarcian) of South Germany. Geologica et Palaeontologica, 42, 23-38.

Thies, D., \& Hauff, R. B. (2011). A new species of Dapedium Leach, 1822 (Actinopterygii, Neopterygii, Semionotiformes) from the Early Jurassic of South Germany. Palaeodiversity, 4, 185-221.

Thies, D., \& Hauff, R. B. (2012). A Speiballen from the Lower Jurassic Posidonia Shale of South Germany. Neues Jahrbuch für Geologie und Paläontologie, Abhandlungen, 267(1), 117-124. https://oi. org/10.1127/0077-7749/2012/0301 .

Thies, D., \& Herzog, A. (1999). New information on $\dagger$ Dapedium Leach 1822 (Actinopterygii, †Semionotiformes). In G. Arratia \& H.-P. Schultze (Eds.), MesozoicFishes 2 - systematics and fossil record. Proceedings of the International Meeting, Buckow 1997 (pp. 143152). München: Verlag Dr. Friedrich Pfeil.

Thies, D., \& Waschkewitz, J. (2015). Redescription of Dapedium pholidotum (Agassiz, 1832) (Actinopterygii, Neopterygii) from the Lower Jurassic Posidonia Shale, with comments on the phylogenetic position of Dapedium Leach, 1822. Journal of Systematic Palaeontology. https://doi.org/10.1080/14772019.2015.1043361.

Thorne, P. M., Ruta, M., \& Benton, M. J. (2011). Resetting the evolution of marine reptiles at the Triassic-Jurassic boundary. Proceedings of the National Academy of Sciences, 108(20), 8339-8344. https://doi. org/10.1073/pnas.1018959108.

Tintori, A. (1983). Hypsisomatic Semionotidae (Pisces, Actinopterygii) from the Upper Triassic of Lombardy (N. Italy). Rivista Italiana di Paleontologia, 88(3), 417-442.

Tintori, A. (1998). Fish biodiversity in the marine Norian (Late Triassic) of northern Italy: The first Neopterygian radiation. Italian Journal of Zoology, 65, 193-198.

Veevers, J. J. (Ed.). (2000). Billion-year earth history of Australia and neighbours in Gondwanaland. Sydney: GEMOC Press.

Wenz, S. (1967). Compléments à l'étude des Poissons Actinoptérygiens du Jurassique français (p. 276). Paris: Cahiers de Paléontologie, CNRS.

Williams, M., Benton, M. J., \& Ross, A. (2015). The strawberry bank Lagerstätte reveals insights into early Jurassic life. Journal of the Geological Society, 172(6), 683-692.

Woodward, A. S. (1895a). Catalogue of the fossil fishes in the British Museum (Natural History). part III. London: Trustees of the British Museum XXIV+544 pp.

Woodward, A. S. (1895b). Fossil fishes of the Talbragar Beds (Jurassic?). Memoirs of the Geological Survey of New South Wales. Paleontology, 9, I-XIII 1-31.

Woodward, A. S. (1929). The Upper Jurassic ganoid fish Heterostrophus. Proceedings of the Zoological Society of London, 99(3), 561-566.

Publisher's note Springer Nature remains neutral with regard to jurisdictional claims in published maps and institutional affiliations. 